Michał Wojciechowski

Uniwersytet Warmińsko-Mazurski, Olsztyn

m.wojciechowski@uwm.edu.pl

ORCID: 0000-0002-5658-7512

DOI: http://dx.doi.org/10.12775/BPTh.2018.004
Biblica

et

Patristica

Thoruniensia

11 (2018) 1: 87-99

ISSN (print) 1689-5150

ISSN (online) 2450-7059

\title{
Metoda egzegetyczna w komentarzu do Apokalipsy Ekumeniusza
}

\section{Exegetical method in the Ecumenius' commentary on the Revelation}

Streszczenie. Ekumeniusz (Oikoumenios), autor komentarza do Apokalipsy, był przypuszczalnie świeckim uczonym greckim z VI w. (adresat listów Sewera). Jest to pierwszy zachowany grecki komentarz do Apokalipsy, choć stoi za nim tradycja wcześniejsza. Metody Ekumeniusza, mimo jego błędów, pokrewne były dzisiejszemu podejściu naukowemu, gdyż szukał on właściwego sensu poszczególnych obrazów, wiązał Apokalipsę z czasami jej powstania i traktował ją całościowo, uwzględniając kompozycję. Nie ulegał natomiast wcześniejszej tendencji do traktowania jej literalnie. Nie widział jej więc jako przede wszystkim proroctwa co do czasów przyszłych. Nie alegoryzował jej też przesadnie, gdyż szukał sensu symbolicznego, w tym alegorycznego, ze względu na charakter literacki dzieła i czasem dla pouczenia odbiorców, a nie na zasadzie fantazyjnej duchowej relektury. Badał teologię księgi, łącząc to z deklaracją ortodoksyjnej chrystologii. Potem, w komentarzu do Apokalipsy Andrzeja z Cezarei, który czerpał z Ekumeniusza, aktualizacja i eschatologizacja jej orędzia przeważyła.

Summary. Ecumenius (Oikoumenios), who wrote a commentary on the Revelation of John, was perhaps a lay Greek scholar from the sixth century A.D., known from Severus' letters (and may be governor of Aphrodisia?). It is the oldest preserved Greek commentary on the Revelation, even if based on earlier traditions. Methods of Ecumenius, in spite of his mistakes, seem near to the modern scholarly approach, because he looked for the intended, correct meanings of images from the text, he explained some of them in their historical context and considered the composition of the book. He avoided an earlier tendency to read the Revelation in a literal way. He did not reduced it to the eschatological prophecy. On the other hand, he avoided an excessive spiritual allegorizing, because he looked for the intended symbolic sense, realizing the literary genre of the book. He studied the theology of the book, declaring an orthodox christology. However, in the later commentary on the Revelation by Andrew of Caesarea, its message was seen as predominantly eschatological and actual.

Słowa klucze: Ekumeniusz; Apokalipsa; komentarze patrystyczne; metoda egzegezy.

Keywords: Ecumenius; Revelation; patristic commentaries; exegetical method. 


\section{Dzieło i autor}

bszerny grecki komentarz do Apokalipsy przekazany pod imieniem Ekumeniusza został odnaleziony w nowszych czasach, a przy tym jest dość późny w zestawieniu z klasycznymi komentarzami biblijnymi Ojców Kościoła. Jest więc w nauce stosunkowo mniej popularny, rzadziej wydawany i tłumaczony. W ostatnich latach wzbudził jednak nowe zainteresowanie, może związane $\mathrm{z}$ poszukiwaniem $\mathrm{w}$ studiach nad starożytnością mniej przebadanych tematów.

Przytoczę tu najważniejsze etapy badań. Podstawowe rękopisy zostały odkryte przez Franza Diekampa i w 1901 roku omówione ${ }^{1}$. Tekst komentarza wydał w 1928 Hoskier, zasłużony dla badań nad tekstem samej Apokalipsy². Jej tekst przekazany w rękopisach Ekumeniusza ma znaczenie dla wydań krytycznych Nowego Testamentu.

Przedmiotem dyskusji stało się datowanie i zabarwienie teologiczne komentarza. Ulepszone wydanie krytyczne dał M. De Groote w 1999 roku$^{3}$. Zainspirowało to przekłady, flamandzki tegoż autora ${ }^{4}$, dwa angielskie ${ }^{5}$ oraz hiszpański ${ }^{6}$, jak też nowe opracowania. Przekład polski planuję, tu prezentuję studium wstępne.

Osoba autora jest mało znana i niepewna ${ }^{7}$. Z powodu imienia łączono ten komentarz z Ekumeniuszem, biskupem Trikki w Tesalii, żyjącym w wieku X, któremu potem były przypisywane rozmaite komentarze do Nowego Testamentu $^{8}$. Ten błąd pokutuje w katalogach bibliotecznych. Koło roku 400 lub później (?) jakiś Ekumeniusz był namiestnikiem Afrodyzji; został po nim posąg z inskrypcją, według której był znawcą praw i łączył muzę italską z pięknem attyckim, co wskazuje na twórczość naukową i literacką. Ten wydaje się zbyt

1 F. Diekamp, Mittheilungen.

2 H.C. Hoskier (ed.), The Complete Commentary.

3 M. De Groote (ed.), Oecumenii Commentarius. Za nim podział na rozdziały, punkty i podpunkty (przyjęty w tłumaczeniu Suggita, zob. niżej). Wykorzystał on 9 rękopisów dzieła i kilkadziesiąt dalszych z urywkami.

4 M. De Groote (opr.), Oecumenius. Verlaring [non vidi].

5 Oecumenius, Commentary, tłum. J.N. Suggit; niezależnie fragmenty w: W.C. Weinrich (opr.), Revelation; całość W.C. Weinrich, T.C. Oden (opr.), Greek Commentaries (lepsze, ale mniej dosłowne).

6 Ecumenio, Commentario.

7 Por. zwł. M. De Groote, Die Quaestio Oecumeniana.

8 Reprodukowane w PG 118-119. 
wczesny i nie wiadomo, żeby się zajmował teologią. ${ }^{9}$ Wspominam go dla kompletności, aczkolwiek, gdyby datować jego inskrypcję i posąg później, byłby może tożsamy z następnym.

Fragment badanego komentarza został zacytowany w rękopisie syryjskim z VII wieku, katenie zabarwionej monofizycko. Stwierdza ona na wstępie, że Ekumeniusz był prawowierny, co potwierdzałyby listy patriarchy Mar Sewe$\mathrm{ra}^{10}$. Chodzi o Sewera z Antiochii, zmarłego w 538 roku. Jeden z listów Sewera do jakiegoś Ekumeniusza określa go słowem komes i zawiera pozdrowienia dla jego żony. Byłby to zatem wykształcony wyższy urzędnik świecki, który tylko okazjonalnie zajmował się teologią. Dlatego nie mamy o nim i o jego dziełach więcej wiadomości.

Ta identyfikacja napotyka na pewne przeszkody ${ }^{11}$. Komentując pierwsze wersety, Ekumeniusz stwierdza, że niektóre proroctwa czekają na realizację, choć upłynęło już ponad 500 lat (1,3,6 - do Ap 1,1-2). Zarazem datuje Apokalipsę na czasy Domicjana. To by wskazywało na powstanie komentarza pod koniec, a nie na początku VI wieku, chyba żeby autor liczył owe 500 lat od Chrystusa.

Następnie Ekumeniusz nie deklarował monofizytyzmu (przy pewnych analogiach do Cyryla z Aleksandrii), lecz starał się trzymać bizantyjskiej ortodoksji chrystologicznej, czemu dał wyraz w wielu ustępach komentarza ${ }^{12}$. Możliwy jest tu wpływ potępienia „trzech rozdziałów” na soborze konstantynopolitańskim II z 553 roku (aczkolwiek nie są one przywołane, a Ewagriusz potępiony na tym soborze spotkał się z pochwałą: $6,3,12)$. Wydarzenie z soboru konstantynopolskiego I (381) zostało wspomniane (12,20,5). Do chalcedońskiego (451), mamy tylko możliwą aluzję $(12,13,6)$. Tożsamość autora jest zatem niepewna, choć łączna waga różnych argumentów może prowadzić o utożsamienia autora komentarza $\mathrm{z}$ adresatem listów Sewera ${ }^{13}$.

9 Por. http://insaph.kcl.ac.uk/ala2004/inscription/eAla031.html.

10 A. Spitaler, J. Schmid, Zur Klärung; por. Weinrich, Oden, Greek Commentaries, xxi. Listy Sewera po syryjsku i w przekładach [non vidi]: E.W. Brooks, The Sixth Book; idem, A Collection of Letters.

11 Już F. Diekamp (Mittheilungen) wolał koniec VI wieku. Por. np. A. Monaci Castagno, Il problema della datazione. Polemizuje z nią J. Lamoreaux, The Provenance, który czyni z Ekumeniusza monofizytę na podstawie scholiów do listów Pawłowych, przechowanych pod jego imieniem.

12 O tej chrystologii obszernie: F.M. Fernández Jimenez, El Comentario sobre el Apocalipsis.

Tak ostatnio Suggit, Commentary, 4-6; Weinrich - Oden, Greek Commentaries, xxiiii-xxiv; Fernández Jimenez, El Commentario, 34-41. Okres późniejszy: De Groote, Questio. 
W każdym razie mamy tu do czynienia z pierwszym zachowanym greckim komentarzem do Apokalipsy, utworem ważnym i dużym. Poprzednie tego typu dzieła zaginęły ${ }^{14}$. Istnieją za to wcześniejsze komentarze łacińskie ${ }^{15}$. Scholia do Apokalipsy, błędnie kiedyś przypisywane Orygenesowi, to zbiór cytatów z kilku autorów od II do IV wieku, przechowanych jako glosy do tekstu Apokalipsy ${ }^{16}$. Świadczą one, że o Apokalipsie sporo pisano. Po Ekumeniuszu, gdzieś około roku 600, stworzył swój krótszy komentarz Andrzej z Cezarei, wpływowy w Bizancjum, potem zaś około 900 roku Aretas z Cezarei.

\section{Swoistość Ekumeniusza}

Ekumeniusz wpisuje się w pewien sposób w historię egzegezy. Jego komentarz do Apokalipsy Ekumeniusza jest jakąś kontynuacją egzegezy patrystycznej, gdyż podejmuje jej rozmaite wątki ${ }^{17}$. Powołuje się więc na wcześniejszych Ojców $^{18}$, naśladuje pewne ich metody, przytacza dawniejsze wyjaśnienia, w tym alegoryczne.

Jednakże bardziej uderzająca wydaje mi się inna okoliczność: to, że Ekumeniusz poszukuje metody naukowej. Pod wieloma względami myśli podobnie jak współcześni badacze Biblii, tak że mógłby uchodzić za prekursora dzisiejszej egzegezy i teologii biblijnej. Nie on jeden oczywiście, gdyż egzegeza nowsza wiele zaczerpnęła $\mathrm{z}$ dawnej. U niego jednak jest to jakby wyraźniejsze. I przy badaniu sensu dosłownego, i w sposobie podejścia do symboliki zawartej w tekście, i przy traktowaniu wniosków teologicznych, Ekumeniusz jako komentator postępował dość podobnie do dzisiejszych. Zwracał też uwagę na związki Apokalipsy z epoką jej powstania.

W historii egzegezy nie podkreślałbym bowiem tego, że obfituje ona w wykwity fantazji komentatorów. Alegoreza, tak pociągająca dla wielu badaczy, należy bardziej do historii literatury niż do nauki. W dodatku stanowi naśladownictwo alegorycznej wykładni mitów w świecie greckim. Efektowne pomysły

14 Ekumeniusz mógł je znać, choć ich nie wymienia. Dość sztuczny podział jego komentarza na 12 mów kojarzy się z pogłoską o istnieniu komentarza Orygenesa do Apokalipsy, wspomnianego w anonimowym komentarzu irlandzkim (invenientur XII homeliae Origenis super hoc opus - por. F.T. Kelly, Early Medieval Evidence).

15 Pol. D. Budzanowska, W. Linke (red.), Pierwsze łacińskie komentarze.

16 Opracowałem je jako: Pseudo-Orygenes, Uwagi do Apokalipsy.

17 O tej w ogólności zob. np. M. Simonetti, Między dosłownościa a alegorią; P. Henne, La Bible et les Pères.

18 Por. M. De Groote, Die Literatur. 
$\mathrm{z}$ tego nurtu przyciągają chyba zbytnią uwagę. Tymczasem najważniejsze w tej historii egzegezy jest mozolne dochodzenie do metody najbardziej adekwatnej, pozwalającej dotrzeć do właściwego sensu tekstu, który potem stanowi konieczną bazę dla rozwinięć rozmaitego rodzaju.

U Ekumeniusza widać, że omawiając teksty zakłada pytanie, jaki jest ich pierwotny i podstawowy sens, zamierzony przez autora. Sens ten nazywamy dziś wyrazowym lub dosłownym ${ }^{19}$. Stronił jednak ten autor od literalizmu, co wynikało ze znajomości sposobu pisania Apokalipsy. Dostrzegał znaczenie kompozycji i całościowej wymowy księgi (ma przykład zauważa, że nie należy w niej szukać sekwencji czasowej zdarzeń; $8,5,3$ ).

Proponując wyjaśnienia symboliczne, unikał jednak zbyt fantazyjnych alegorii, szukając w miarę możliwości znaczeń symbolicznych rzeczywiście zawartych w tekście ${ }^{20}$. Na bazie tekstu i w konfrontacji z resztą Biblii wyprowadzał wnioski teologiczno-biblijne, a zwłaszcza chrystologiczne, ale nie zastępowały one egzegezy, lecz funkcjonowały jako jej przedłużenie. Choć jego objaśnienia są nieraz mylne, sam ich cel i metoda mogą się nam wydać bliskie. Zobaczymy to potem na przykładach.

Postępowanie Ekumeniusza jest więc dość odległe od hermeneutyki Orygenesa, dla którego rzeczywistości zmysłowe są z założenia symbolem wyższych rzeczywistości duchowych. U Ekumeniusza sens dosłowny jest ważny, choć często może być uzupełniony albo zastąpiony objaśnieniem symbolicznym. Przy Ap 8,8-9 $(5,11)$ autor rozróżnia świadomie sens dosłowny i zmysłowy (pros to gramma; to aistheton) płonącej góry i krwawego morza, od objaśnienia symbolicznego na zasadzie analogii (kata ten anagogen kai tous tes tropes) ${ }^{21}$.

\section{Pogląd na Apokalipsę}

Na wstępie i w trakcie komentarza Ekumeniusz wypowiada ogólne poglądy na Apokalipsę. Umie osadzić księgę w historii, którą zna dobrze. Datuje ją na czasy Domicjana, co zgadza się z przeważającą opinią obecną 22 . Mówi o tym także w zakończeniu $(1,21,1 ; 2,13,9 ; 12,20,6)$, powołując się zwłaszcza na Euzebiusza z Cezarei. Wykorzystuje tę datę przy objaśnianiu tekstów, na przykład kojarząc niektóre opisy klęsk z losem Żydów podczas wojny z lat 66-70 (4,17,1-8;

\footnotetext{
19 Por. Katolicki komentarz biblijny, 1789-1793 (R.E. Brown).

20 Podobne sugestie: P.G.R. de Villiers, History, Mysticism.

21 Weinrich - Oden, Greek Commentaries, xxiii.

22 Por. M. Wojciechowski, Apokalipsa, s. 52-55.
} 
$5,17,4)^{23}$ - zna notabene Józefa Flawiusza. Identyfikuje wielką nierządnicę i Babilon jako symbole Rzymu (do Ap 17-18).

Zgodnie z panującą w jego czasach opinią, za autora Apokalipsy uważał Ekumeniusz Jana ewangelistę, czemu stale daje wyraz. Kwestia ta została dokładniej przedstawiona we wstępie i w zakończeniu jego komentarza. O ile jednak w kwestii daty powstania Ekumeniusz wskazuje czasy Domicjana jako okoliczność faktyczną, to w przypadku tożsamości jej autora wchodzi w spór. Emocjonalnie i retorycznie atakuje pogląd przeciwny. Odwołuje się też do swoich poprzedników.

Na wstępie (1,1,1-7) przytacza całą listę mistrzów: Atanazy (List 39), Bazyli (Przeciw Eunomiuszowi 2,14), Grzegorz z Nazjanzu (Mowy 42,1), Metody (O zmartwychwstaniu 2,28,5), Cyryl Aleksandryjski (De adoratione et cultu in spiritu et veritate 6), Hipolit (komentarz do Daniela 3,9,10). Chodzi mu przy tym raczej o autorytet Apokalipsy, gdyż podważanie autorstwa ewangelisty kojarzy z podważaniem jej wartości.

Jest to więc raczej rozstrzygnięcie teologiczne dotyczące kanoniczności, niż osąd historyczny. $Z$ tego względu zaczyna swoje dzieło od cytatu z $2 \mathrm{Tm}$ 3,16, że wszelkie Pismo jest natchnione przez Boga i pożyteczne. W zakończeniu dziela $(12,20,1-6)$ powołuje się natomiast w tej sprawie na cytowanie obok siebie Ewangelii i Apokalipsy przez Bazylego (Przeciw Eunomiuszowi 4), na aluzję u Grzegorza z Nazjanzu (Mowy 42,8-9) oraz na Euzebiusza (Historia Kościoła 3,1,1; 3,18,1-3). Można jednak odnieść wrażenie, że nie jest pewien swojego stanowiska i dlatego podpiera się cudzym autorytetem, swoistymi "przypisami”.

Ich pojawienie się jest o tyle znamienne, że skądinąd Ekumeniusz cytuje dość mało autorów wcześniejszych. Imion autorów chrześcijańskich jest mniej niż dwudziestu, łącznie $\mathrm{z}$ herezjarchami, a pogańskich i żydowskich kilku. Przeważnie są to odwołania poboczne ${ }^{24}$. Autor nie wymienia innych komentarzy do Apokalipsy.

Gdy Ekumeniusz cytuje Ewangelię św. Jana, traktuje ją więc zwykle jako ilustrację do Apokalipsy, pochodzącą od tego samego autora. Nie nadużywa jednak tej metody, gdyż cytatów takich wcale nie jest dużo (23 teksty w 29 miejscach), mniej niż z Ewangelii św. Mateusza. Objaśnianie tekstów biblijnych przez paralele jest zresztą praktykowane od starożytności po dziś. Pismo jest interpretowane przez Pismo. Odpowiada to podejściu, które obecnie można by

23 Ta propozycja, prawie nieznana dzisiaj, wydaje się całkiem uzasadniona.

24 Najobszerniejszy cytat to Testimonium Flaviani w 4,10,8 (Józef Flawiusz, Dawne dzieje Izraela 18,63-64). 
nazwać teologiczno-biblijnym i kanonicznym z jednej strony, a intertekstualnym $\mathrm{z}$ drugiej.

Zakładając, że Biblia jest całością, autor stale przytacza zatem jej teksty jako pomoc do zrozumienia Apokalipsy i jako jej inspirację. Najczęstsze księgi to Księga Rodzaju, Wyjścia, Psalmy, Księga Izajasza, Daniela. Biorąc pod uwagę mnogość zamierzonych aluzji biblijnych w Apokalipsie, metoda ta, mimo szeregu potknięć, wydaje się poprawna.

Ekumeniusz nie stawia na sposób dzisiejszy kwestii gatunku literackiego Apokalipsy, ale go rozumie. We wprowadzeniu pisze $(1,1,2)$, że Apokalipsa jest wysoce mistyczna (mystikotaten), zawierając tajemnice. Bliskie jest to pojęciu literatury objawieniowej, która z założenia ma wtajemniczać, oznajmiać tajemnice w języku symbolicznym, odpowiednim do ich natury. Apokalipsa objaśnia głębszy sens historii.

O jej wartości świadczy to, że stanowi proroctwo, czyli wypowiedź podaną od Boga. Proroctwo nie jest jednak zawężone do przepowiadania przyszłości, co przy interpretacji Apokalipsy często się zdarzało i zdarza. Owo zawężenie wydaje się odzwierciedlać takie właśnie pojmowanie roli wyroczni i wróżb w świecie antycznym - podczas gdy w Biblii prorok, hebr. nabi, to rzecznik Boga, a nie wróżbita. Ekumeniusz powołuje się tu jednak na Homera, stwierdzając, że wieszczący znają „wydarzenia teraźniejsze, przyszłe i przeszłe” (1,1,2; por. Iliada 1,70: Kalchas wiedział „wszystko, co było, co jest i co miało nastąpić”). ${ }^{25}$ Następnie mówi autor o potrzebie wyjaśniania rzeczy duchowych, co wydaje się aluzją do pojęcia „sensu duchowego”, wskazywanego przez interpretację alegoryczną.

Widzi więc Ekumeniusz symboliczny charakter pisarstwa Apokalipsy, choć nazywa to inaczej. Widzi także, że z racji takiej formy wypowiedzi można stosować Apokalipsę do czasów jej powstania, można w niej szukać zapowiedzi co do zdarzeń późniejszych i oczywiście co do czasów ostatecznych. Ta ostatnia perspektywa jednak nie dominuje, i to programowo. Jest to konkluzja poprawna, ale w historii interpretacji niezbyt częsta. Już u Andrzeja z Cezarei sens eschatologiczny i alegoryczny będzie przeważał. Choć eschatologii oczywiście nie pomija, Ekumeniusz bardziej jest zaabsorbowany chrystologią i soteriologią Apokalipsy, co bliskie jest odczytaniom dzisiejszym. 


\section{Przykłady egzegezy Ekumeniusza}

Wykład Ekumeniusza jest zwykle dość systematyczny. Rozdziały poprzedzone są wstępami. Objaśnienia zaczynają się metodą komentarzy od ustępu omawianego, lemmy. Brak uwag o krytyce tekstu. Potem wyjaśniane są poszczególne wyrażenia i symbole. Po nich następuje dość często komentarz do całości. Po drodze często są przytaczane biblijne teksty paralelne. Komentarz teologiczny, a zwłaszcza chrystologiczny, pojawia się osobno na końcu. Zastosowań do życia chrześcijańskiego mamy niewiele. Jest to struktura pracy naukowej, a nie kazania.

Przy Ap 1,12-16, wstępnej wizji Syna Człowieczego, objaśnione są kolejne elementy (1,27): siedem świeczników jako kościoły, szaty jako strój kapłański, białe włosy jako odwieczność, płomień ognia jako groźba. Trudno by to istotniej poprawić. W trudnym słowie chalkolibanon, jakby „spiż kadzidlany”, dostrzega aluzję do jakości brązu, oczyszczania metali w ogniu, dobrego kadzidła koloru miedzi zwanego „męskim”, stóp jako podstawy ciała. To dopiero prowadzi do konkluzji chrystologicznej.

Znajomość rozmaitych realiów okazuje się jak widać sporą pomocą. Krótkie odwołania do nich są dość częste. Siedem trąb to element scenariusza paruzji, przez analogię do wjazdu królewskiego (Ap 8,2; komentarz 5,5,6). Dym ze studni w Ap 9,2 wskazuje na obecność ognia i ciemność zarazem $(5,17,3)$.

Inny przykład to uwaga do Ap 16,13, „duchy nieczyste jak żaby”. Autor powiada, że żaby mają upodobanie w błocie i ściekach (wtedy bez chemikaliów...), a demony chcą, by ludzie tak żyli jak one $(9,5,4)$. Obserwacja z życia prowadzi do pasującego do sytuacji sensu symbolicznego, a ten do pouczenia. Komentatorzy nowsi, nie widząc sensu we wzmiance o żabach, widzieli w niej często wtórny dopisek. Jest to pomniejszy przykład, który jednak dobrze ilustruje trzy poziomy egzegezy Ekumeniusza: historyczny, symboliczny względnie duchowy (pomyślany zwykle jako odtworzenie zamysłu autora) oraz moralny (aplikacyjny) ${ }^{26}$.

Klucz Dawida z Ap 3,7 $(2,13,3)$ to symbol władzy, na podobieństwo zarządzania domem, podobnie jak w Mt 16,19. Dawid rządził widzialnym Izraelem, Chrystus Izraelem duchowym, $\mathrm{z}$ wyższym daleko autorytetem (podobnie o Zwiastowaniu w Łk 1,32-33). Władza boskiego Chrystusa jest najwyższa i ostateczna.

26 Por. P.G.R. de Villiers, History. 
Arche tes ktiseos z Ap 3,14 to nie początek stworzenia, lecz jego władcza zasada, Ekumeniusz słusznie wybiera to drugie znaczenie arche, nawet jeśli chodzi mu nie tyle o filologię i sens filozoficzny, ile o polemikę z arianizmem.

Skądinąd autor jest dość ostrożny. Czasem daje poznać, że rozwiązanie proponowane nie jest pewne $(3,7)$ : dwudziestu czterech starców z Ap 4,4 rozumie jako postacie ze Starego i Nowego Testamentu, ale ich listę tylko zgaduje. Podaje zaraz potem poprawne objaśnienie siedmiu pochodni, duchów Boga (Ap 4,5), jako po prostu archaniołów. Komentatorzy po dziś dzień lubią szukać tu na siłę aluzji do Ducha Świętego. Cztery istoty żywe (Ap 4,6-8; komentarz 3,9,1-4) nie są ewangelistami, lecz serafinami, którzy reprezentują cztery żywioły. ${ }^{27}$ Jest to myśl swoista, ale czwórka rzeczywiście jest powszechnym symbolem kosmicznym. Adresatami listów do siedmiu Kościołów są ich aniołowie, angeloi; wcześniejsza egzegeza widzi w nich duchy opiekuńcze, a u Ekumeniusza chodziłoby o same lokalne Kościoły (2,3), reprezentację Kościołów chrześcijańskich.

Problemem bywa wybór między sensem dosłownym a alegorycznym. Gwiazda i gorzkie wody z Ap 8,11 mogą mieć sens symboliczny, ale dosłowny również jest możliwy $(5,13)$. Przy królach i kapłanach z Ap 5,10 zaczyna od rozumienia dosłownego, ale dorzuca i przenośne $(4,3,7)$. W Ap 6,15-16 szuka sensu alegorycznego dla opisu ludzi kryjących się w jaskiniach (chodziłoby o demony), ale zarazem dopuszcza inspirację wspomnień o wojnie żydowskiej $(4,15,8)$. Przy ogniu niszczącym część ziemi w Ap 8,7 wybiera autor sens metaforyczny, wewnętrzne cierpienia grzeszników. Argumentuje jednak, że autor go zamierzył, a sens dosłowny byłby niewystarczający. Widzi zatem, że sens symboliczny wymaga dowodu. Analogicznie wskazuje, że krew aż po wędzidła koni to metafora (Ap 14,20; por. 8,19,6-8).

Pewne objaśnienia odzwierciedlają jednak tradycje późniejsze, którym Ekumeniusz ulega. Egzegeza Ap 12 jest już maryjna $(6,19)$, choć w rzeczywistości „niewiasta obleczona w słońce” to symbol ludu Bożego, o czym wcześniejsi pisarze chrześcijańscy wiedzieli. Doszła tu do głosu osobista pobożność.

Kiedy indziej autor idzie pod prąd. Wbrew katastroficznemu postrzeganiu Apokalipsy znajduje w niej, i słusznie, orędzie zbawcze, tonując obrazy przemocy w księdze ${ }^{28}$. W szczegółach błądzi, ale trafnie ten wymiar dowartościowuje. Na przykład zwój zapisany dwustronnie z Ap 5,1 zawiera imiona zbawionych z Izraela i z pogan $(3,13,2)$; dla porównania, mały zwój z Ap 10,2 zawierałby imiona ukaranych, całkiem bezbożnych, daleko mniej liczne $(6,3,5)$. Przy te-

27 Notabene ich polska nazwa kojarzy się z życiem. Skądinąd cztery „żywioły, elementy", stoicheia, tak naprawdę oznaczają stany skupienia (ciało stałe, ciecz, gaz i plazma).

28 Por. P.G.R. de Villiers, The Understanding of Violence; tenże szerzej: Coping with Violent Scripture. 
macie gniewu Bożego przypomina autor o Bożym miłosierdziu $(8,13)$; spotykamy tu podejście teologiczno-biblijne, które szuka sensu Biblii jako całości. Przy obrazowych opisach kar autor stwierdza, że prawdziwa męka potępionych polega na odcięciu od dobrego Boga $(8,13,3-8)$.

Swoiste dla Ekumeniusza jest rozumienie otwarcia siedmiu pieczęci jako objawienia dzieł zbawczych Chrystusa. W czterech jeźdźcach z Ap 6 widzi zatem konsekwentnie znaki pomyślne, co jest nieuzasadnione i sztuczne, nawet w odniesieniu do pierwszego jeźdźca, z powodu białego konia kojarzonego nieraz z Chrystusem. Jego objaśnienia są jednak konsekwentne i dość pomysłowe: drugi jeździec to konflikt z powodu Chrystusa, trzeci z wagą to sprawiedliwość, czwarty to rozgromienie demonów i bałwochwalców (4,6-11); głód dotyczyłby duchowego łaknienia. Adekwatna jest natomiast egzegeza Ap 7, gdzie „sto czterdzieści cztery tysiące” oznacza symbolicznie ogromną liczbę zbawionych spośród Żydów $(4,17)$, do których dołączają nieprzeliczone tłumy z innych narodów (5,2-3). Nowe przymierze jest jakby ogromnym „dziedzińcem (dla) pogan" (6,9,4-6; por. Ap 11,2).

Symbolika liczb jest dostrzegana, ale wykorzystuje ją autor dość powściągliwie $^{29}$. Wielokrotnie mowa o siódemce i dziesiątce jako symbolach pełni. Czterdzieści dwa miesiące to czas Nowego Przymierza, obecny, ograniczony w porównaniu z wiecznością $(6,9,8)$. Znaczenia 666 (Ap 13,18) szuka autor za pomocą gematrii i stwierdza wielość możliwości, co należy uznać, chociaż propozycje szczegółowe są zupełnie chybione $(8,5,5-9)$.

Co do identyfikacji bestii z morza (Ap 13,1) Ekumeniusz się waha, czy byłaby ona podwładnym Szatana, czyli smoka, czy nim samym, czy też personifikacją jego działań w świecie obecnym. Nie kojarzy jej natomiast z imperium rzymskim. Jak już wspomniałem, przy Ap 17-18 mowa jednak o Rzymie; nierząd objaśniono przy tym słusznie i biblijnie jako bałwochwalstwo (np. 9,8,3).

Natomiast bestia z ziemi z Ap 13,11 jest wielokrotnie utożsamiana z Antychrystem, a więc należy już do eschatologii $(7,11,1 ; 8,3,1 ; 9,5,3 ; 9,11,3-4)$. Argument jest taki, że imituje ona Chrystusa jako baranka $(8,3,2)$. W konsekwencji klęski z Ap 16 należą do epoki eschatologicznej, gdyż czasza wylana na tron bestii oznaczać ma rozgromienie Antychrysta $(9,3,3)$. Potem jednak interpretacja eschatologiczna pojawia się, poprawnie, dopiero przy rozdziale 19 Apokalipsy, gdzie po upadku Babilonu, węża i Antychrysta pojawia się boski Chrystus na białym koniu (końcowe dwa rozdziały komentarza Ekumeniusza, 11-12).

Jednakże objaśnienie tysiącletniego królestwa (Ap 20,1-3) nie jest eschatologiczne - idea to oryginalna i skądinąd nieznana. Autor utożsamia ten tysiąc

29 Por. P.G.R. de Villiers, Numerical Symbolism. 
lat z jednym dniem w oczach Boga, a ten $z$ „dniem zbawienia” (Iz 49,8). Dlatego związanie Szatana kojarzy ze zbawczym wcieleniem Chrystusa $(10,17)$. Natomiast rozwiązany z powrotem byłby on w czasie obecnym, w którym żyjemy. Stosownie do tego pierwsze zmartwychwstanie to życie wiary w Duchu Świętym. Kojarzenie tego tysiąca lat $\mathrm{z}$ losem dusz po śmierci oraz z dalszą przyszłością jest odrzucone.

Potem o przyszłości mowa zdaniem Ekumeniusza od Ap 20,8 (Antychryst, zmartwychwstanie, sąd, doskonała więź małżeńska Chrystusa z Kościołem, życie przyszłe w Bogu symbolicznie nazwane nową Jerozolimą). W tej partii autor trzyma się znaczeń podanych w samym tekście Apokalipsy i je rozwija. Czasy ostateczne to zamieszkanie zbawionych w nowej Jerozolimie, soteriologia w Apokalipsie splata się z eschatologią. Autor oczekuje zbawienia w czasach ostatecznych raczej niż „końca świata”.

\section{Bibliografia}

\section{Źródła}

Budzanowska D., Linke W. (red.), Pierwsze łacińskie komentarze do Apokalipsy. Hipolit, Wiktoryn, Hieronim, Tykoniusz, Florilegium. Studia Classica, Mediaevalia et Neolatina 1, Warszawa 2011.

De Groote M. (ed.), Oecumenii Commentarius in Apocalypsin, Traditio exegetica graeca 8, Lovanii 1999.

De Groote M. (ed.), Oecumenius. Verlaring ven de Apokalyps, Gent 2009.

Ecumenio, Commentario sobre el Apocalipsis, opr. L.F. Mateo-Seco, Biblioteca de Patristica 76, Madrid 2008.

Hoskier H.C. (ed.), The Complete Commentary of Oecumenius on the Apocalypse, University of Michigan Studies. Humanistic Series, Ann Arbor 1928 (Google books).

Oecumenius, Commentary on the Apocalypse, tłum. J.N. Suggit, Fathers of the Church 112, Washington 2006.

Oecumenius, Oecumenii, Triccae in Thessalia episcopi, opera omnia, Patrologia Graeca 118-119, Paris 1864.

Schmid J., Studien zur Geschichte des griechischen Apokalypse-Textes. I. Der ApokalypseKommentar des Andreas von Kaisareia. 1. Text, Münchener Theologische Studien I, Historische Abteilung 1, Erganzüngsband, München 1955.

Weinrich W.C. (ed.), Revelation, Ancient Christian Commentary on Scripture XII, Downers Grove 2005.

Weinrich W.C., T.C. Oden (ed.), Greek Commentaries on Revelation. Oecumenius and Andrew of Cesarea, Ancient Christian Texts, Downers Grove 2012. 
Wojciechowski M. (opr.), Pseudo-Orygenes, Uwagi do Apokalipsy, Mała Biblioteka Ojców Kościoła 4, Kraków 2005.

\section{Opracowania}

Baynes L., Revelation 5:1 and 10:2a, 8-10 in the Earliest Greek Tradition: A Response to Richard Bauckham, Journal of Biblical Literature 129 (2010) 4, s. 801-816.

Brooks E.W., A Collection of Letters of Severus of Antioch from Numerous Syriac Manuscripts, Patrologia Orientalis 12(1915)2.

Brooks E.W., The Sixth Book of the Select Letters of Severus Patriarch of Antioch in the Syriac Version of Athanasius of Nisibis, t 1-2, Oxford/London 1902-1904.

De Groote M., Die handschriftliche Überlieferung des Oecumenius-Kommentars zur Apokalypse, Sacris Erudiri 35 (1995), s. 5-29.

De Groote M., Die Kirchenväter in Oecumenius" «Scholia in Iohannem Chrysostomum», Vigiliae Christianae 55 (2001) 2, s. 191-200.

De Groote M., Die Literatur der Kirchenväter im Apokalypsekommentar des Oecumenius, Zeitschrift für Antikes Christentum 7 (2003) 2, s. 251-262.

De Groote M., Die Quaestio Oecumeniana, Sacris Erudiri 36 (1996), s. 67-105.

De Groote M., Die Scholien aus dem Oecumenius-Kommentar zur Apokalypse, Sacris Erudiri 35 (1995), s. 31-43.

De Groote M., Die Scholien aus dem Oecumenius-Kommentar zur Apokalypse : kritische Herausgabe, Sacris Erudiri 37 (1997), s. 111-131.

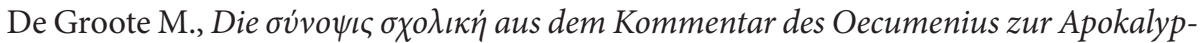
se, Sacris Erudiri 32 (1991) 2, s. 107-119.

De Groote M., Grammatischer Index zum Apokalypsekommentar des Oecumenius, Glotta 79 (2003), s. 29-61.

De Groote M., Index Oecumenianus, Alpha - Omega: Reihe A, Lexika, Indizen und Konkordanzen zur klassischen Philologie 223, Hildesheim i in. 2001.

De Groote M., Opera (Pseudo-)Oecumeniana: das sonstige echte und vermeinte Oeuvre des Apokalypse-Exegeten Oecumenius, Byzantinische Zeitschrift. Supplementum bibliographicum 94 (2001) 1, s. 20-29.

Diekamp F., Mittheilungen über den neugefundenen Commentar des Oekumenius zur Apokalypse, Sitzungsberichte der Königlichen Preussischen Akademie der Wissenschaft 43 (1901), s. 1046-1056.

Durousseau C., The Commentary of Oecumenius on the Apocalypse of John: A Lost Chapter in the History of Interpretation, Journal of the Chicago Society of Biblical Research 29 (1984) 1, s. 21-34.

Fernández Jimenez F.M., El Comentario sobre el Apocalipsis de Ecumenio en la controversia cristológica del siglo VI en Byzancio, Toledo 2013.

Henne P., La Bible et les Pères, Paris 2010.

Hoskier H.C., The Lost Commentary of Ecumenius on the Apocalypse, The American Journal of Philology 34 (1913) 3, s. 300-314. 
Kelly F.T., Early Medieval Evidence for Twelve Homilies by Origen on the Apocalypse, Vetera Christianorum 39(1985), s. 273-279.

Lamoreaux J., The Provenance of Ecumenius" "Commentary on the Apocalypse», Vigiliae Christianae 52 (1998) 1, s. 88-108.

Monaci Castagno A., I commenti di Ecumenio e di Andrea di Cesarea. Due letture divergenti dell'Apocalisse, Memorie dell'Accademia delle Scienze di Torino. Serie V. 2, Classe di Scienze morali, storiche e filologiche 5 (1981), s. 303-426.

Monaci Castagno A., Il problema della datazione dei Commenti all'Apocalisse di Ecumenio e di Andrea di Cesarea, Atti della Accademia delle Scienze di Torino. 2, Classe di Scienze Morali, Storiche e Filologiche 114 (1980), 223-246.

Perry P.S., The Rhetoric of Digressions: Revelation 7:1-17 and 10:1-11:13 and Ancient Communication, Wissenschaftliche Untersuchungen zum Neuen Testament II/268, Tübingen 2012.

Ryan S.M., Hearing at the Boundaries of Vision: Education Informing Cosmology in Revelation 9, Library of New Testament Studies 448, London 2012.

Schmid J., Der Apokalypse-Text des Oikumenios, Biblica 40 (1959), s. 935-942.

Schmid J., Oekumenios der Apokalypsen-Ausleger und Oekumenios der Bischof von Trik$k a$, Byzantinisch-neugriechische Jahrbücher 14 (1938), s. 322-330.

Simonetti M., Między dosłownością a alegorią, Kraków 2000.

Spitaler A., Schmid J., Zur Klärung des Oekumeniusproblems, Oriens Christianus 31 (1934), s. 208-218.

Villiers P.G.R. de, Entering the Corridors of Power: State and Church in the Reception History of Revelation, Acta Theologica 33 (2013) 2, s. 37-56.

Villiers P.G.R. de, History, Mysticism and Ethics in Oecumenius: A Hermeneutical Perspective on the Earlies Extant Greek Commentary on Revelation, Studia Historiae Ecclesiasticae 33 (2007), s. 315-336.

Villiers P.G.R. de, Numerical Symbolism in Oecumenius's Commentary on Revelation, w: Tot Sacramento quot verba, red. K. Huber i in., Münster 2014, s. 135-152.

Villiers P.G.R. de, The Understanding of Violence in Oecumenius Greek Commentary on Revelation, Acta Patristica et Byzantina 20 (2009), 232-245; szerzej: Coping with Violent Scripture in a Time of Peace and Prosperity. The Interpretation of Revelation in the Greek Commentary of Oecumenius, w: Ancient Christian Interpretations of "Violent Texts" in the Apocalypse, J. Verheyden, A. Merkt, T. Nicklas (red.), Göttingen 2011, s. 180-198.

Wojciechowski M., Apokalipsa świętego Jana, Nowy Komentarz Biblijny. Nowy Testament 20, Częstochowa 2012. 